\title{
Relația dintre teorie și realitate la Eugeniu Coșeriu şi José Ortega y Gasset
}

\author{
Cristinel Munteanu ${ }^{\star}$ \\ Facultatea de Comunicare și Relații Internaționale, Universitatea „Danubius”, Bd. Galați 3, 800654 Galați, România
}

\section{Despre articol}

Istoric:

Primit 3 octombrie 2019

Acceptat 13 octombrie 2019

Publicat 7 noiembrie 2019

Cuvinte-cheie:

lingvistică

filosofie

teorie

realitate

studiu empiric

\begin{abstract}
Rezumat
Folosind ca pretext un citat despre teorie atribuit lui José Ortega y Gasset (18831955), citat pe care Eugeniu Coșeriu (1921-2002) 1-a reprodus deformat într-o prelegere ținută în limba română (în 1992), îmi propun-dincolo de identificarea lucrării filosofului spaniol din care a fost extras citatul în cauză — să fac o prezentare a concepțiilor celor doi savanți cu privire la raportul dintre teorie și realitate sau, altfel spus, dintre teorie și faptele investigate. La prima vedere, cele două concepții par similare, cu atît mai mult cu cît cei doi gînditori dau frecvent impresia că aparțin aceleiași mari familii de gîndire. Voi încerca să arăt aici în ce puncte sînt convergente, respectiv divergente cele două viziuni, evidențiind, totodată, unele consecințe care derivă din ele, de interes și pentru filosofia limbajului.
\end{abstract}

\section{Preliminarii}

La 11 martie 1992, cu ocazia primirii titlului de doctor honoris causa al Universității „Babeș-Bolyai” din Cluj-Napoca, Eugeniu Coșeriu a ținut în fața celor prezenți la ceremonie o prelegere referitoare la principiile lingvisticii ca știință a culturii. Prelegerea respectivă a fost consemnată și publicată, în același an, în revista "Apostrof”" . Tema nu era una nouă, savantul avînd obiceiul să expună în astfel de împrejurări principiile cercetării de tip umanist, principii care l-au călăuzit permanent (fie și intuitiv sau implicit, la început) în activitatea sa știinţifică (Coșeriu, 1992a,b, 1993, 1997b, 1999, 2004a,b).

$\mathrm{Nu}$ voi insista aici asupra principiilor ca atare (al realismului, al umanismului, al tradiției, al antidogmatismului și al responsabilității sociale), pe care Coșeriu le-a prezentat pentru prima dată, într-o formă explicită și justificată, în discursul de recepție prilejuit de alegerea sa, în 1977, ca membru al Academiei de Științe din Heidelberg (Coșeriu, 1977)2. Vreau doar să subliniez că, dincolo de firescul nucleu comun al tuturor acestor discursuri, prelegeri sau conferințe, există—pe alocuri—și unele „variațiuni”. Este motivul pentru care, în primele secțiuni ale acestui articol, mă voi ocupa de un element singular (probabil), și anume un citat din Ortega y Gasset pe care Coșeriu pare să-l fi întrebuințat numai în amintita prelegere de la Cluj; în acest scop, voi încerca să expun și concepția lui Coșeriu despre relația dintre teorie și realitatea limbajului. După ce voi fi elucidat originea citatului analizat, voi căuta să determin, în celelalte părţi ale articolului, în ce măsură era îndreptăţit Coșeriu să recurgă la Ortega y Gasset ca suport pentru afirmațiile sale despre aplicarea teoriilor lingvistice. Se înțelege că un asemenea demers mă obligă să prezint—fie și în linii mari-şi concepția lui Ortega despre raportul dintre teorie şi realitate.

Fiind vorba de o temă de etică a științei, Coșeriu invocă-în sprijinul concepției sale lingvisticediverşi filosofi care l-au influențat mai mult sau mai puțin în perioada formării sale: Platon, Hegel, Husserl,

\footnotetext{
*Adresă de corespondență: munteanucristinel@yahoo.com.

${ }^{1}$ Precizez că o parte a acestui studiu (vizînd obiective parțial diferite), ca articol de sine stătător, se află în curs de publicare într-un volum omagial îngrijit de colegii de la Universitatea „Babeș-Bolyai” din Cluj-Napoca.

${ }^{2}$ Ultimul principiu, cel al responsabilităţii sociale (sau al utilităţii publice), nu apare formulat explicit în respectivul discurs de recepție, deoarece Coșeriu va fi ținut, pesemne, să prezinte cu acel prilej doar principiile cercetării ca atare, lăsînd deoparte principiul omului de știință văzut ca membru al unei comunități (sau „cetăți”).
} 
Cristinel Munteanu

Leibniz ș.a. După cum avea să o mărturisească mai tîrziu, într-o conferință ținută la Madrid (Coșeriu, 1999, p. 41), pe José Ortega y Gasset Eugeniu Coșeriu avea să-l descopere și să-l prețuiască abia la sfirș̦itul anilor '50, în Uruguay, cînd concepția sa lingvistică era deja bine închegată. În consecință, Coșeriu va apela la Ortega, uneori, pentru a dobîndi o confirmare suplimentară a ideilor pe care și le formase (cele mai multe dintre ele) în mediul științific italian (cf. și Munteanu, 2019a).

\section{Teorie și studiu empiric în lingvistică}

Care este, în definitiv, citatul lui Ortega pe care îl voi comenta în continuare? În prelegerea de la Cluj, Coșeriu recurge la gînditorul spaniol într-un punct al discursului său. Astfel, ajungînd la cel de-al doilea principiu al cercetării, principiul umanismului sau al „cunoașterii originare” (după Husserl), Coșeriu apreciază că există mai multe corolare ale acestuia, dar se oprește doar la cel pe care îl consideră cu adevărat fundamental:

„Este vorba de unitatea permanentă—în lingvistică și în alte științe ale culturii, însă în lingvistică în mod particular, fiindcă aici au existat atîtea devieri-între teorie și studiu empiric. $\mathrm{Nu}$ are niciun sens, dacă aici plecăm de la ceea ce este bekannt, să construim teorii independente de fapte și să se spună, cum s-a spus uneori, că dacă teoria nu se aplică realității, tant pis pour la réalité; nu, de vină în acest caz este, oricum, teoria și nu realitatea. Filosoful spaniol Ortega, vorbind despre această aberație, a teoriilor inaplicabile, spunea: «Una teoría que no se aplica no es una teoría, es una estupidez». Și pentru fapte, aceasta înseamnă același lucru: nu există, în realitate, studiu empiric fără o teorie, cel puțin intuitivă, la bază. Un studiu empiric bine făcut, bine realizat, este deci și o contribuție la teorie, aşa cum teoria este întotdeauna teorie a faptelor, teoria nefiind altceva decît recunoașterea universalului în particular, în concret”.

(Coșeriu, 1992a, p. 11 și 14)

Înainte de a examina citatul extras din opera lui Ortega, voi face cîteva precizări la temă. Despre legătura dialectică dintre teorie și studiul faptelor Coșeriu discutase și cu alte ocazii, și chiar și înainte de acel discurs de recepție, din 1977, de la Academia din Heidelberg. O făcuse și în românește: de pildă, într-un interviu din 1974 acordat lui Nicolae Saramandu ${ }^{3}$ :

„După convingerea mea, teoria nu este o construcție arbitrară și abstractă. Ea este, mai întîi, intuiția universalului în fapte și, apoi, formularea explicită și reflectată a acestui universal. Asta înseamnă, pentru mine, trei lucruri: (1) Nu există nicio opoziție reală între studiul faptelor și studiul teoretic. Teoria este întotdeauna teoria realității și nu o construcție a priori. (2) Tocmai pentru că teoria este reflectarea universalului prezent în fapte, realitatea nu poate fi ignorată. E nevoie să cunoști fapte. Nu e adevărat că teoria este valabilă chiar dacă nu se aplică, fiind contrazisă de fapte. (3) Teoria nu este un model abstract, care se aplică faptelor, ci chiar fundamentul cercetării empirice, pe care îl ai-într-o măsură—în mod intuitiv înainte de examinarea faptelor, în timpul cercetării lor și după încheierea cercetării. Între teorie și fapte există un raport dialectic: cercetarea faptelor depinde de teorie, dar, în același timp, influențează teoria, astfel că teoria, la sfîrșitul cercetării, nu mai este aceeași cu care ai început”.

(Coșeriu, 1996, p. 164-165)

Pe această linie, voi mai reproduce un paragraf din nota preliminară pe care Coșeriu a scris-o pentru cartea sa din 1978 (reeditată în 1987), Gramática, semántica, universales:

\footnotetext{
${ }^{3}$ Interviul în cauză va fi reluat apoi, ca anexă, în cartea-interviu Lingvistica integrală realizată de Nicolae Saramandu în anii '90 (Coșeriu, 1996).
} 
„Teoria, în sensul său primar și autentic, este aprehensiunea universalului în concret, în «faptele» înseși. Prin urmare, nu există nici distanță, nici conflict între «fapte» (sau investigație «empirică ») și teorie, ci investigația empirică şi teoria sînt două forme complementare ale aceleiași activităţi. O prezentare și interpretare rațională a unui fapt este, în același timp, o contribuție la teorie; iar o teorie veritabilă este, în același timp, interpretare rațională a «faptelor»”.

(Coșeriu, 1987, p. 10; trad. mea, Cr.M.) ${ }^{a}$

Această idee privind influența reciprocă, dinspre teorie către studiul faptelor și invers, i-a fost sugerată lui Coșeriu (ori confirmată) de o concepție estetică. Dacă Benedetto Croce afirmase că în artă intuiția coincide cu expresia, John Dewey, în schimb, susținuse că expresia, deși pleacă de la intuiţie, se întoarce asupra celei din urmă și o corectează, o nuanțează ș.a.m.d. Ideea i-a plăcut savantului român atît de mult, încît a adaptat-o la problemele care îl interesau în mod deosebit (Munteanu, 2015, p. 137).

\section{O contaminație ideatică intratextuală}

Dar să revenim la acea frază (citată mai sus) pe care Coșeriu o pune pe seama marelui gînditor José Ortega y Gasset: „Filosoful spaniol Ortega, vorbind despre această aberație, a teoriilor inaplicabile, spunea: «Una teoría que no se aplica no es una teoría, es una estupidez»”. Fiindcă expunerea a fost una orală, nu avem o trimitere exactă la un text anume din opera (foarte întinsă) a lui Ortega y Gasset. Este destul de sigur că Eugeniu Coșeriu nu s-a folosit de vreo însemnare în acest caz, ci s-a bazat pe propria memorie (excepțională, de altminteri). Faptul că lingvistul român a ținut să ofere asistenței citatul direct în spaniolă, și nu în traducere, ar pleda pentru o reproducere fidelă a cuvintelor lui Ortega. Și totuși, de data aceasta, memoria pare să-i fi jucat feste lui Coșeriu, dar într-un fel motivat, aș zice. Vom vedea imediat cum.

Cineva ar putea crede că, avînd la îndemînă seria de „opere complete” (Obras Completas) ale lui Ortega y Gasset în format $p d f$, care îți permite să verifici rapid de cîte ori apar cuvintele teoría, aplica, estupidez în fiecare volum, este foarte ușor să descoperi citatul cu pricina. Lucrurile nu stau deloc așa. Căutările de acest tip, pe care le-am efectuat pe întregul corpus aflat la dispoziție, nu au scos nimic la iveală ${ }^{4}$. Abia la lectura atentă a tuturor traducerilor românești existente (însumînd 15 volume; Ortega y Gasset, 1972, 1973a, 1995, 1997a,b, 1999a,b,c,d,e, 2000, 2001, 2002, 2004, 2007) am descoperit ceea ce ar putea fi sursa citatului „misterios”. Contextul revelator-compus din două secvențe aflate în capitole alăturatese găsește în această carte a lui Ortega: Una interpretación de la historia universal (en torno a Toynbee) sau, după cum s-a transpus în românește, $O$ interpretare a istoriei universale (pornind de la Toynbee). Astfel, în capitolul al X-lea, criticînd metoda empirică a istoricului britanic Arnold Toynbee (care raportase în mod defectuos nașterea unor civilizații din trecut la anumite rase), Ortega y Gasset spune în felul următor:

„Între paranteze. Deunăzi, pentru a nu părea că-l pun pe seama lui Toynbee, acest om al metodei empirice, însă care nu știe ce să facă cu un fapt ca acesta, atît de clar și pe care, firește, nu poate nici măcar să-l recunoască drept fapt, nu am spus că teoria cunoașterii și metodologia actuală știu perfect că acestei metode empirice i se întîmplă ce se întîmpla cu impozitele la Roma, după cum arată faimosul text al unui profesor din Salamanca, și anume, se aplică, dar nu există. $\mathrm{Nu}$ există metodă empirică în sensul pe care îl pretinde Toynbee. Toată știința este constructivă și construcția este contrariul empirismului; de aceea, empirism înseamnă cu exactitate contrariul metodei. $\mathrm{Cu}$ totul altul este rolul pe care îl au faptele în construcția unei teorii”.

\footnotetext{
ấn original: „La teoría, en su sentido primario y genuino, es aprehensión de lo universal en lo concreto, en los «hechos» mismos. No hay, por consiguiente, ni distancia ni conflicto entre «hechos» (o investigación «empírica») y teoría, sino que la investigación empírica y la teoría son dos formas complementarias de la misma actividad. Una presentación e interpretación racional de un hecho es al mismo tiempo una contribución a la teoría; y una teoría auténtica es al mismo tiempo interpretación racional de «hechos»" (Coșeriu, 1987, p. 10).

${ }^{4}$ Este și aceasta o dovadă în plus că omul nu poate fi înlocuit (încă) pretutindeni și în orișice privință de computer. Acesta din urmă poate fi programat să găsească / identifice anumite lucruri, dar nu poate descoperi (deocamdată) anumite relații între acele lucruri, așa cum o face omul, mai ales în domeniile în care sensul joacă un rol determinant.
} 
Sare în ochi, deocamdată, această formulare: „....acestei metode empirice i se întîmplă ce se intîmpla cu impozitele la Roma [...], se aplică, dar nu există" (,... a ese método empírico le acontece lo que a los impuestos en Roma [...], que es que empiezan por no existir"). După cum se observă, doar în traducerea românească apare verbul a aplica; în originalul spaniol, sensul ar fi următorul: '...încep prin a nu exista' ${ }^{6}$. Chiar dacă traducătorul român a redat bine conținutul, versiunea sa este mai puțin fidelă și ne-ar putea induce în eroare în acest caz. Totuși, ceea ce contează este continuarea, în care apare și termenul teorie: „Toată știința este constructivă și construcția este contrariul empirismului; de aceea, empirism înseamnă cu exactitate contrariul metodei. $\mathrm{Cu}$ totul altul este rolul pe care îl au faptele în construcția unei teorii”. Într-adevăr, în acest paragraf, dar chiar și mai departe în același volum (Ortega y Gasset, 1999c, p. 274-275), concepția despre teorie a lui Ortega se vădește a fi compatibilă (în linii mari) cu cea a lui Coșeriu; deci, este posibil ca acest paragraf să-i fi reținut, mai întîi, atenția savantului român. Însă încă nu am ajuns la ceea ce ne interesează, adică la un enunț similar celui rostit de Coșeriu în acea prelegere. Ei bine, în capitolul învecinat, al XIlea, criticindu-l iarăși pe Toynbee (fiindcă nu acordase și secetei, alături de potop, cuvenita însemnătate mitologică), Ortega face, la un moment dat, acest comentariu într-o consistentă notă de subsol:

„Cînd am făcut deunăzi aluzie la mitul potopului, m-am referit, desigur, la acea tradiție sumeroacadiană care era cea despre care vorbim. Mai ales că a numi ceva un mit nu înseamnă că i se neagă un fond de realitate. Dimpotrivă. Nimic nu este mit dacă nu este extras din măduva unei experiențe umane reale. Cînd aceasta lipsește, nu se numește «mit», se numește pur și simplu «prostie». Este dureros și o rușine ca aceste observații să fie necesare și să apară aceste rezerve care ar trebui să fie inutile pentru persoane de o cultură medie, însă nu știu ce plutește în aerul intelectual al Spaniei de azi pentru că se pare că aici stau suspendate o ignoranță şi o monotonie a minţii într-adevăr dureroase care obligă la asumarea tuturor acestor precauții grotești”.

(Ortega y Gasset, 1999c, p. 296-297)

În consecință, contextul originar (introdus, ca și în celălalt paragraf, tot prin expresia el otro día 'deunăzi') pare să fie acesta referitor la mit: „Nimic nu este mit dacă nu este extras din măduva unei experiențe umane reale. Cînd aceasta lipsește, nu se numește «mit», se numește pur și simplu «prostie»”. Mitul este și el o explicație, un fel de „teorie naivă” cu privire la realitate; în felul acesta s-ar justifica suprapunerea celor două concepte- 'teorie' ${ }^{8}$ și 'mit' —și substituirea operate de Coșeriu. În originalul spaniol apare însă cuvîntul tontería (care rimează cu teoría), și nu estupidez: „Nada es mito si no lleva dentro la médula de una

\footnotetext{
${ }^{5}$ Aici și în continuare evidențierile cu italice îmi aparțin. În original, textul sună astfel: „Entre paréntesis. El otro día, por no parecer que hacía una carga sobre Toynbee, este hombre del método empírico pero que no sabe qué hacer con un hecho como este, tan claro y que, naturalmente, no puede menos de reconocer como hecho, no dije que la teoría del conocimiento y la metodología actuales saben perfectamente que a ese método empirico le acontece lo que a los impuestos en Roma, según el famoso texto de un profesor de Salamanca, que es que empiezan por no existir. No hay método empírico en el sentido que pretende Toynbee. Toda ciencia es constructiva y la construcción es lo contrario del empirismo; por eso empirismo es lo más contrario que cabe del método. Otra cosa es el papel que tengan los hechos en la construcción de una teoría" (Ortega y Gasset, 1965b, p. 182).

${ }^{6}$ Și într-o prelegere din 1940, Ortega trimisese la respectivul text spaniol (de pe la 1900) despre dreptul roman (și la formula referitoare la impozite), apreciind că era un text naiv (Ortega y Gasset, 1984, p. 44-45).

${ }^{7}$ În original: „Cuando el otro día aludí al mito del diluvio me refería, claro está, a esta tradición sumerio-acadia, que era de lo que hablábamos. Sobre que llamar a algo mito no supone que se le niegue un fondo de realidad. Todo lo contrario. Nada es mito si no lleva dentro la médula de una experiencia humana real. Cuando esto falta no se le llama «mito», se le llama simplemente «tonteria». Es una pena y una vergüenza que sea menester hacer estas observaciones y poner estas reservas, que debían ser innecesarias para personas medianamente cultas, pero yo no sé qué hay en el aire intelectual de España hoy que parece que en él están suspendidas una ignorancia y una insipidez demente verdaderamente penosas, que obligan a tomar todas estas precauciones grotescas" (Ortega y Gasset, 1965b, p. 197-198).

${ }^{8}$ Neîndoielnic, despre teorie (sau teorii) discută Ortega și în (multe) alte locuri (vezi, de exemplu, Ortega y Gasset, 1999d, p. 84-85 și 116), însă în niciun alt loc din opera sa nu am găsit „teoria inaplicabilă” pusă în relație cu prostia.
} 
experiencia humana real. Cuando esto falta no se le llama «mito», se le llama simplemente «tontería»”. Este posibil ca înlocuirea sinonimică să fi fost făcută de Coșeriu sub efectul termenului insipidez, aflat, în același comentariu, puțin mai încolo, într-un frază privitoare tot la neștiință: „...una ignorancia y una insipidez demente verdaderamente penosas” (,...o ignoranță și o monotonie a minţii într-adevăr dureroase”).

Luînd ca model sintagme terminologice deja existente în lingvistică, precum contaminație lexicală și contaminație frazeologicăa am putea spune că avem de-a face aici cu un fel de contaminație ideatică intratextuală, întrucît Coșeriu dă impresia că a contopit într-o frază două idei aflate în paragrafe diferite din aceeași operă filosofică.

Dată fiind pasiunea lui Coșeriu pentru istorie în general, cred că era absolut normal ca el—imediat ce va fi avut ocazia—să fi citit Una interpretación de la historia universal (en torno a Toynbee), alături de Historia como sistema (pe care o citase, încă din 1957, în Sincronía, diacronía e historia). Dacă o atare lectură îmi pare destul de sigură, în schimb nu știu care va fi fost distanța în timp (cu impact asupra memoriei) între momentul lecturii respective și momentul citării prilejuite de prelegerea de la Cluj. În orice caz, astfel de investigații, odată finalizate, ne aduc aceleași satisfacții pe care le trăim, bunăoară, atunci cînd descoperim (și propunem) o nouă etimologie.

\section{Ortega y Gasset și teoria în calitate de construcție imaginară}

Ne putem întreba acum dacă își va fi format Coșeriu, în urma lecturilor, o opinie adecvată cu privire la modul în care înțelegea Ortega conceptul de 'teorie științifică'. În lipsa unei tratări mai dezvoltate a acestei probleme (de vreme ce nu am descoperit ca E. Coșeriu să fi scris măcar cîteva paragrafe laolaltă despre Ortega), nu putem face aici decît unele presupuneri mai mult sau mai puțin argumentate.

Dacă Eugeniu Coșeriu ar fi citit anumite cărți ale lui José Ortega y Gasset (En torno a Galileo, La idea de principio en Leibniz y la evolución de la teoría deductiva, Sobre la razón histórica etc.), el ar fi observat, probabil, că filosoful spaniol nu avea deloc tendința să asocieze 'teoria' cu 'prostia' (nici ca tontería, nici ca estupidez), nici măcar atunci cînd cea dintîi avea prea puțin de-a face cu realitatea. Pentru Ortega, teoria reprezintă o construcție a imaginației omului de știință, o construcție mentală menită să orienteze cercetarea (Ortega y Gasset, 1984, p. 64). De altminteri, chiar în cartea $O$ interpretare a istoriei universale, la cîteva paragrafe distanță de locul deja examinat, Ortega insistă asupra caracterului de construcție imaginară al teoriilor științifice. Referindu-se la o idee proprie, potrivit căreia „conturul geografic generează civilizația”, Ortega o consideră o idee excelentă, adăugînd:

„Însă această idee nu este empirică; este exact contrariul, este o ipoteză, și orice ipoteză este o construcție și de aceea este știință autentică; de aceea este o teorie autentică. Ideile, în măsura în care merită acest nume exigent, nu sînt niciodată o simplă receptare de presupuse realităţi, ci sînt construcții de posibilități; așadar, imagini pure care ne aparțin sau idei pure, așa cum a demonstrat acum douzeci și patru de secole, odată pentru totdeauna, Platon din Atena, fiul lui Ariston; demonstrație care, după mine, nu poate fi comparată cu nici o alta, fiind descoperirea sublimă și cea mai eficace făcută pînă acum pe planeta pe care o locuim, și care azi, mai mult ca oricînd, reprezintă alfa și omega ale oricărui exercițiu științific”.

$$
\text { (Ortega y Gasset, 1999c, p. 274-275) } 9
$$

Dar fiindcă Eugeniu Coșeriu era interesat îndeosebi de științele umaniste ori culturale, modul său de a pune problema (atrăgîndu-l în discuție, ca atare, și pe Ortega y Gasset) este explicabil. Pornind de la conceptul

\footnotetext{
9̂̂n original: „Pero esa idea no es empírica; es todo lo contrario, es una hipótesis, y toda hipótesis es una construcción, y por eso es auténtica ciencia, por eso es auténtica teoría. Las ideas, en cuanto merecen este exigente nombre de ideas, no son nunca mera recepción de presuntas realidades, sino que son construcciones de posibilidades; por tanto, puras imaginaciones nuestras o ideas puras, según averiguó hace veinticuatro siglos, de una vez para siempre, Platón de Atenas, hijo de Aristón; averiguación que, a mi entender, es, sin comparación posible con ningún otro, el descubrimiento más sublime y eficaz que se ha hecho hasta ahora en el planeta que habitamos y que hoy más que nunca constituye el alfa y omega de todo ejercicio científico" (Ortega y Gasset, 1965b, p. 184).
} 
de 'cunoaștere originară' (lansat de Husserl), Coșeriu era convins că-în cazul științelor umaniste-omul (de știință) are o intuiție sigură cu privire la activitățile culturale, deoarece el este subiectul (autorul) acestor activităţi. Prin urmare, în cazul lingvisticii (văzută ca știință a culturii), lingvistul pleacă sau ar trebui să plece întotdeauna de la intuiția sa sigură (o cunoaștere nereflexivă) de vorbitor. Din acest motiv (și pe acest teren), Coșeriu ajunge să aprecieze că o teorie care nu are legătură cu realitatea (limbajului) este „una estupidez”. Mai mult decît atît, el obișnuia să întrebuințeze termenul de ipoteză numai cu referire la științele naturii, adică îl rezerva exclusiv pentru domeniul în care o astfel de „teorie” este abandonată sau respinsă dacă, în urma verificării (ori a experimentului), nu corespunde defel realității investigate (Coșeriu, 1992a, p. 11 sau 2000, p. 49-54).

Într-adevăr, Ortega y Gasset are în vedere, cu precădere, științele naturii (și, desigur, științele formale sau matematice) atunci cind vorbește despre teorii în calitatea lor de construcții ale imaginației. Lucrul acesta se vădește mai cu seamă în studiile pe care le-a dedicat unor gînditori precum Galileo și Leibniz. De pildă, după Ortega, unul dintre marile merite ale lui Galileo rezidă în faptul de a fi dovedit—prin exemplul cercetărilor proprii din domeniul fizicii, construind mental și ideal o „realitate” — că știința este atît un rezultat al imaginației, cît și al observației, o „descoperire” (sau „invenție”) pe care filosoful spaniol o consideră valabilă și pentru domeniul științelor istorice:

„Ei bine, am convingerea că se apropie o splendidă înflorire a științelor istorice, deoarece istoricii vor reuși să trateze faptele istorice, mutatis mutandis, la fel cum Galileo începuse să trateze faptele fizice. Se vor convinge că știința—prin care se înțelege toată știința despre lucruri, fie acestea corporale ori spirituale—este atît un produs al imaginației, cît și al observației, și că cea din urmă nu este posibilă fără cea dintîi; pe scurt, că știința este construcție”.

(Ortega y Gasset, 1964, p. 17; trad. mea, Cr.M.) $)^{10}$

În felul acesta, datorită caracterului său imaginativ, știința devine o soră a poeziei, cu precizarea—adaugă Ortega—că între imaginația lui Galileo și cea a unui poet există o deosebire radicală: imaginația lui Galileo este una exactă.

Încă și mai explicit este Ortega în cartea despre Leibniz, în care se ocupă, printre altele, și de trăsăturile științei moderne, cu o atenție specială pentru „teoria fizică”, despre care ajunge să afirme (,în termeni vulgarizatori”, după cum o admite) următoarele: „ceea ce teoria fizică ne spune, conținutul său, nu are nimic de-a face cu Realitatea despre care ne vorbește” (Ortega y Gasset, 1965a, p. 78; trad. mea, Cr.M.) ${ }^{11}$. Particularitățile acestui tip de exercițiu intelectual sînt prezentate astfel:

„Modul de gîndire practicat de «teoria fizică » începe prin a închide în ea însăși acea teorie și a crea în mediul său fantastic o lume-sistem, ordine sau serie—de obiecte care nu seamănă deloc cu fenomenele reale. Acel sistem imaginar intrateoretic, chiar prin faptul de a fi imaginar (ca toată matematica), reușește să fie neechivoc”.

(Ortega y Gasset, 1965a, p. 80; trad. mea, Cr.M.) ${ }^{12}$

$\mathrm{Cu}$ ajutorul experimentului, se compară apoi într-o manieră neechivocă ordinea obiectelor „fantastice” cu cea a fenomenelor reale pentru a se determina măsura în care cele din urmă alcătuiesc un sistem izomorf

\footnotetext{
${ }^{10}$ În original: „Pues bien, yo tengo la convicción de que se avecina un espléndido florecimiento de las ciencias históricas debido a que los historiadores se resolverán a hacer mutatis mutandis, frente a los hechos históricos, lo mismo que Galileo inició frente a los físicos. Se convencerán de que la ciencia, se entiende toda ciencia de cosas, sean éstas corporales o espirituales, es tanto obra de imaginación como de observación, que esta última no es posible sin aquella—en suma, que la ciencia es construcción” (Ortega y Gasset, 1964, p. 17).

${ }^{11}$ În original: „...en términos vulgares: lo que la teoría física nos dice, su contenido, no tiene que ver con la Realidad de la cual nos habla” (Ortega y Gasset, 1965a, p. 78).

${ }^{12}$ În original: „El modo de pensar que ejercita la «teoría física» comienza por encerrar a esta dentro de sí misma y crear en su ámbito fantástico un mundo-sistema, orden o serie-de objetos que no se parecen nada a los fenómenos reales. Ese sistema imaginario intrateórico, por lo mismo que es imaginario (como toda matemática), logra ser inequívoco" (Ortega y Gasset, 1965a, p. 80).
} 
cu sistemul celor dintîi. Așadar, experimentul (atunci cînd rezultatul este unul pozitiv), și nu similaritatea, garantează corespondența dintre cele două serii / sisteme (cf. și Ortega y Gasset, 1963, p. 68).

Pentru Ortega, Platon este cel care anticipează prin „metoda” sa știința modernă, și nu Aristotel. Stagiritul pornește (în ceea ce privește „adevărurile”) de la opinia publică sau de la „simțul comun”, menținînduse foarte aproape de lucruri și considerînd că proximitatea maximă a minții față de realitate este asigurată de senzație. Platon, în schimb, procedează cu totul altfel:

„Cînd Platon vrea să cunoască un lucru care se află în apropierea sa, prima acțiune pe care o întreprinde este să o ia la fugă în direcția opusă, să se îndepărteze la infinit de el, să meargă dincolo de stele, și apoi, revenind dintr-un «loc supracelest», să vadă ce se poate spune cu sens despre lucrurile acestei lumi care sînt atît de lipsite de sens. Această platonică fugă în vederea abordării îmi pare cea mai genială invenție de ordin teoretic care a avut loc vreodată pe această planetă; nimic altceva nu se poate compara cu ea”.

(Ortega y Gasset, 1965a, p. 156-157; trad. mea, Cr.M.) ${ }^{13}$

Altfel spus, faptele (asemenea unor hieroglife care trebuie interpretate pentru a ajunge la mesajul dindărătul lor) acoperă realitatea autentică. Pentru a ajunge la ea, omul de știință se retrage în sine mai întîi, construiește o realitate imaginară pură, apoi revine (ieșind din respectiva izolare mentală) cu această „teorie” construită, comparînd-o cu faptele reale care îl înconjoară. Dacă faptele realităţii imaginate se potrivesc cu faptele reale înconjurătoare, atunci înseamnă că realitatea (acoperită de faptele-hieroglife acum descifrate) a fost descoperită (Ortega y Gasset, 1958, p. 12-13).

Evident, din aceea că o invenție genială-procedeul construirii teoriei în imaginație-este utilă științei în general nu rezultă că toate teoriile produse astfel sînt bune. (Chiar la Platon se găsesc destule explicații eronate.) De exemplu, Ortega însuși-în pofida admirației sale pentru celebrul filosof francez-combate teoria lui Descartes despre 'conștiență’ (Ortega y Gasset, 1984, p. 45 și urm.), tocmai fiindcă se dovedește a fi doar o construcție imaginară.

În astfel de cazuri, pentru mai multă rigoare, filosoful spaniol amintește o distincție proprie la care ține foarte mult, aceea dintre 'idei' și 'credințe' (Ortega y Gasset, 1999b). După cum omul este încredințat (fără a acorda atenție, de obicei, acestui amănunt) că pămîntul pe care merge îi suportă greutatea sau că, ieșind din casă, va găsi înaintea ochilor aceeași stradă binecunoscută, tot aşa el poate avea încredere în puterea rațiunii ca atare, fără să se încreadă neapărat și în ideile zămislite de ea. Credințele (care, în concepția lui Ortega, alcătuiesc cultura veritabilă) conferă siguranță vieții noastre, în timp ce ideile nu au în mod necesar această calitate. Teoria (sau „ideea”) este, în principiu, practicabilă sau aplicabilă (iar partea serioasă a unei teorii o constituie chiar aplicarea ei, praxis-ul), dar-ține Ortega să sublinieze-teoria în sine este nonrealitate și imaginație (Ortega y Gasset, 1984, p. 34).

Mai rămîne să lămurim de ce Ortega a susținut (v. supra) că și istoria (ca știință) procedează asemănător fizicii, operînd cu realități construite de imaginație. Această analogie este valabilă numai în punctul de plecare. Confruntat cu problema corpurilor care se mișcă (într-o diversitate de moduri și de direcții), Galileo avea nevoie să stabilească o schemă sau o diagramă a mișcării, să „imagineze” —în primă instanţăo structură esențială și permanentă care să corespundă ulterior mișcărilor variate pe care el le observa. Altminteri, știința fizicii ar fi fost imposibilă. În opinia lui Ortega, istoria trebuie să opereze cu un concept similar, și anume cu o structură obiectivă a vieții, un fel de diagramă a vieții omenești în general (Ortega y Gasset, 1958, p. 18-19). În consecință, misiunea istoriei ar fi, pentru el, aceea de a cerceta în ce măsură a variat această structură de-a lungul epocilor, care au fost schimbările pe care le-a înregistrat ea în cursul evoluției / devenirii omului (Ortega y Gasset, 1958, p. 29). În acest scop, munca istoricului este, de fapt,

\footnotetext{
${ }^{13}$ În original: „Cuando Platón quiere conocer una cosa que está a su vera, lo primero que hace es echar a correr en dirección opuesta, alejarse infinitamente de ella, irse más allá de los astros, y desde un «lugar supraceleste», viniendo en retorno, ver qué se puede decir con sentido sobre las cosas de este mundo que tanto carecen de él. Esta platónica fuga para acercarse me parece la invención más genial que en el orden teorético se ha hecho en el planeta, sin que quepa comparársele ninguna otra" (Ortega y Gasset, 1965a, p. 156-157).
} 
una de reconstrucție mentală a condițiilor obiective în care s-au petrecut anumite evenimente majore. Este necesar ca istoricul să interpreteze, să procedeze hermeneutic, fiind obligat—cînd vrea să înțeleagă, de pildă, un document dintr-o epocă veche-să aibă în vedere ori să afle cît mai mult din viața acelui autor (Ortega y Gasset, 1958, p. 17). Sînt exemplare, în acest sens, chiar studiile pe care Ortega y Gasset le-a dedicat unor pictori spanioli faimoși, precum Velázquez și Goya (Ortega y Gasset, 1972).

Pe această linie, hermeneutica practicată (și teoretizată) de Ortega se aseamănă destul de mult cu hermeneutica practicată (și teoretizată) de Robin George Collingwood, mai ales cînd vine vorba despre ceea ce filosoful britanic numea „reconstituirea gîndului (din) trecut în propria minte a istoricului”, „incapsularea trecutului în prezent" ș.a.m.d. La o atare hermeneutică aderase și Coșeriu, punînd-o efectiv la lucru întru elucidarea unor probleme de etimologie sau de istorie a limbii (Munteanu, 2013).

\section{Idealism și realism lingvistic}

Întrucît am început de la Coșeriu și de la lingvistică, se cuvine să încheiem în mod similar, evidențiind o altă convergență între concepția savantului român și cea a lui Ortega y Gasset (cf. Munteanu, 2019b). Coșeriu a susținut, cu diverse ocazii, că idealismul (lingvistic) este orientarea cea mai potrivită pentru cei care se ocupă de problemele limbajului: „Da, idealismul lingvistic, care pentru mine este nu idealism, ci este realism lingvistic, cum a spus apoi domnul Copceag într-un articol” (Coşeriu, 1996, p. 10) ${ }^{14}$. Deși tributar, într-o măsură însemnată, idealismului (ca viziune filosofică, îndeosebi) ${ }^{15}$, Coșeriu a acceptat ca doctrina sa lingvistică să fie caracterizată prin sintagma „realism lingvistic”, deoarece (după cum o declara frecvent) își construise teoria într-un mod coerent și unitar pornind întotdeauna de la realitatea limbajului ${ }^{16}$ şi criticîndu-i pe cei care procedaseră invers, adică printr-un „veritabil transitus ab intellectu ad rem” (Coșeriu, 1997a, p. 15) ${ }^{17}$.

Să remarcăm că aceste două concepte (orientări)—'idealismul' și 'realismul'—nu sînt antagonice nici în filosofia ca atare, odată ce sînt înțelese corespunzător. José Ortega y Gasset făcuse încă din anul 1910 (într-un studiu de estetică, Adán en el Paraiso ["Adam în Paradis”]) cîteva observații interesante în legătură cu utilizarea improprie a termenului idealism. El susținea că (în contemporanitatea sa) ajunsese să fie considerat drept idealist „cel care încearcă să introducă în climatul ambient proiecte adecvate altor clime, cel care umblă adormit prin lume” („el que trata de introducir en el clima ambiente proyectos adecuados a otros climas, el que camina dormido por el mundo"), adică o persoană romantică și visătoare. Filosoful spaniol ținea atunci să precizeze care ar fi trebuit să fie interpretarea corectă a termenului:

„Istoric vorbind, cuvîntul idee vine de la Platon. Și Platon a numit idei conceptele matematice. Și le-a numit astfel simplu și exclusiv pentru că sînt niște instrumente mentale ce slujesc la construirea lucrurilor concrete. Fără numere, fără plus și minus, care sînt idei, acele presupuse realități sensibile pe care le numim lucruri n-ar exista pentru noi. Așa încît pentru o idee este esențială aplicarea ei la concret, aptitudinea ei de a fi realizată. Adevăratul idealist nu copiază, aşadar, nebulozitățile naive care-i trec prin creier, ci se cufundă cu fervoare în haosul presupuselor realități și caută în ele un principiu de orientare pentru a le domina, pentru a pune cu toată puterea stăpînire pe res, pe lucruri, care îi sînt unica preocupare și unica muză. Idealismul ar trebui să se numească la drept vorbind realism".

\footnotetext{
${ }^{14}$ Într-un articol omagial din 1981 (publicat în spaniolă), Dumitru Copceag propusese denumirea de realism lingvistic pentru teoria lingvistică a lui Coșeriu (vezi Copceag, 2002, p. 100).

${ }^{15}$ S̆ consemnăm amănuntul că—parafrazînd titlul unei celebre lucrări aparținîndu-i lui Karl Vossler, Positivismus und Idealismus in der Sprachwissenschaft (publicată la Heidelberg în 1904)-lingvistul K. Rogger a scris articolul Idealismus und Realismus in der Sprachwissenschaft (apărut în „Zeitschrift für romanische Philologie”, 75 (5-6), 1959, p. 403-438).

${ }^{16}$ Vezi, de pildă, cele spuse de Coșeriu în anii '60, cînd avea deja în proces de structurare „una teoría lingüística coherente y, al mismo tiempo, conforme al objeto lenguaje" (Coșeriu, 1967, p. 7).

${ }^{17}$ Idee afirmată şi astfel: „Aparentele conflicte dintre rațiune și realitate sînt întotdeauna conflicte ale rațiunii cu sine însăşi, căci nu realitatea trebuie să se adapteze intelectului, ci viceversa” (Coșeriu, 1997a, p. 15).
} 
(Ortega y Gasset, 2000, p. 90-91) ${ }^{18}$

Punctele de vedere ale celor doi-Coșeriu și Ortega - sînt, măcar parțial, diferite. Coșeriu este, în esență, aristotelic, cînd vine vorba de cunoaștere și de limbaj, în timp ce Ortega rămîne platonic și în aceste privințe. „Captarea universalului în faptul concret” este o idee care străbate ca un fir roșu concepția lui Coșeriu, și aceasta se vădește din felul în care definește el fie 'semnificatul lingvistic', fie 'teoria', fie 'literatura (artistică)' (Munteanu, 2010, p. 112-113). Mergînd pe urmele lui Aristotel, Coșeriu era încredințat că semnificatele (sau conceptele) iau naștere printr-o operație a intelectului numită de Stagirit (în De anima) "cunoașterea indivizibilului" (nóesis tôn adiairéton ori, în terminologia scolasticilor, apprehensio simplex), o operație prin care se obține intuiția unitară a unui mod de a fi sau, altfel spus, esența lucrurilor (Munteanu, 2012). În schimb, Ortega aplică (ori admite) „rețeta” lui Platon nu doar în zona formării teoriilor, ci chiar și în regiunea apariției semnificatelor / conceptelor (cf. Ortega y Gasset, 1999d, p. 391-398). El susține că, pentru a cunoaște un lucru „prins” în realitatea permanent mișcătoare, este necesar caplecînd, totuși, de la acesta prin abstragerea unor trăsături-să ne retragem în sinea noastră (în „lumea” lui Platon) elaborînd conceptul (sau „ideea”) aferent(ă). Reîntorcîndu-ne apoi asupra lumii, direcționăm conceptul / ideea înspre lucru pentru a-l cunoaște mai bine (Ortega y Gasset, 1984, p. 100-115). Pentru o mai bună înțelegere a întregii problematici, ar fi nevoie să prezentăm in extenso teoria lui Ortega privind cunoașterea, concepția sa despre intelect (cu logicitatea acestuia vs. ilogicitatea realităţii) ${ }^{19}$ etc., dar nu putem intra în amănunte, fiindcă discuția ar depăşi cadrul pe care ni l-am propus aici ${ }^{20}$.

\section{Concluzii}

Să ne reamintim că, în viziunea lui Coșeriu, teoria (mai ales cînd ne referim la domeniul științelor umaniste) „nu este o construcție arbitrară și abstractă” (v. supra, Sec. 2). După cele expuse, cred că putem conchide că Ortega y Gasset, deși vedea în teorie „o construcție imaginară”21, ar fi fost și el de acord că o teorie nu trebuie să fie „arbitrară”. În construcția unei teorii se pleacă întotdeauna, mai mult sau mai puțin, de la realitate. Cît despre „substratul” filosofic diferit al concepțiilor celor doi savanți, s-ar părea că deosebirile nu sînt chiar atît de ireconciliabile... În acest sens, merită amintită o reflecție a filosofului A. N. Whitehead: Aristotel „a disecat pești avînd în cap gîndurile [=ideile] lui Platon” (Whitehead, 1967, p. 107). Aceasta vrea să însemne-explică filosoful britanic - că Stagiritul, chiar dacă va fi pornit de la activitatea teoretică a lui Platon, a învățat să treacă „dincolo de teorie către observarea directă a detaliilor”, modificînd, corectînd sau infirmînd ideile magistrului său.

\footnotetext{
${ }^{18}$ În original: „Históricamente, la palabra idea procede de Platón. Y Platón llamó ideas a los conceptos matemáticos. Y los llamó así pura y exclusivamente porque son como instrumentos mentales que sirven para construir las cosas concretas. Sin los números, sin el más y el menos, que son ideas, esas supuestas realidades sensibles que llamamos cosas no existirían para nosotros. De suerte que es esencial a una idea su aplicación a lo concreto, su aptitud a ser realizada. El verdadero idealista no copia, pues, las ingenuas vaguedades que cruzan su cerebro, sino que se hunde ardientemente en el caos de las supuestas realidades y busca entre ellas un principio de orientación para dominarlas, para apoderarse fortísimamente de la res, de las cosas, que son su única preocupación y su única musa. El idealismo verdaderamente habría de llamarse realismo" (Ortega y Gasset, 1966, p. 486).

${ }^{19}$ În opinia lui Ortega, inteligența (sau rațiunea) funcționează în manieră logică (fiindcă intelectul este singurul din Univers care se conduce după principiul identității). Întrucît s-a crezut multă vreme (și încă se mai crede) că tot ceea ce este real este și rațional (sau, altfel spus, că realitatea și rațiunea au o structură ori fibră comună; altminteri, cunoașterea celei dintîi de către cea de-a doua nu ar fi posibilă), persistă tendința ca în procesul cunoașterii să fie adaptată realitatea la intelect, și nu invers (Ortega y Gasset, 1984, p. 113).

${ }^{20}$ Cf., totuși, Martínez del Castillo (2011), pentru înfățișarea concepției lui Ortega y Gasset. Îmi exprim rezerve însă față de modul în care J. G. Martínez del Castillo-pentru a dezvolta o lingüistica del decir-combină ideile lui Coșeriu despre limbaj cu cele ale lui Ortega.

${ }^{21}$ Fără îndoială, omul de știință are nevoie de imaginație în activitatea sa, și nu doar în sensul avut în vedere de Ortega y Gasset. De pildă, John Dewey aprecia că imaginația umple golurile, „rotunjește” ansamblul, atunci cînd teoria cuiva nu beneficiază de toate datele empirice necesare (similar, pesemne, felului în care un arheolog / restaurator reconstituie pentru muzeu un străvechi vas de lut din care au mai fost găsite doar cîteva fragmente).
} 


\section{Bibliografie}

Copceag, D. (2002). „Realismul lingvistic” sau doctrina științifică a lui Eugenio Coseriu [1981], traducere de Eugenia Bojoga, în „Limba română” (Chișinău), 12 (10), p. 100-107.

Coșeriu, E. (1967). Teoría del lenguaje y lingüistica general. Cinco estudios [1962], segunda edición, Editorial Gredos, Madrid.

Coșeriu, E. (1977). Antrittsrede an der Heidelberger Akademie der Wissenschaften, în „Jahrbuch der Heidelberger Akademie der Wissenschaften" [für 1977], p. 107-108.

Coșeriu, E. (1987). Gramática, semántica, universales. Estudios de lingüistica funcional [1978], segunda edición revisada, Editorial Gredos, Madrid.

Coșeriu, E. (1992a). Principiile lingvisticii ca știință a culturii, în „Apostrof”, 3 (11), p. 11 și 14.

Coșeriu, E. (1992b). Principiile lingvisticii ca știință a culturii, în vol. Omul și limbajul său. Studia linguistica in honorem Eugenio Coseriu (= „Analele științifice ale Universitații «Al. I. Cuza» din Iași”, Serie nouă, Secțiunea III, e, Lingvistică, tom XXXVII-XXXVIII, 1991-1992), Iași, p. 11-19.

Coșeriu, E. (1993). Discurso pronunciado con motivo de su investidura como doctor honoris causa, în vol. Discursos pronunciados en el acto de investidura de doctor honoris causa del Excelentísimo Señor Eugenio Coseriu, Universidad de Granada, Granada, p. $21-35$.

Coșeriu, E. (1996). Lingvistica integrală, interviu cu Eugeniu Coșeriu, realizat de Nicolae Saramandu, Editura Fundației Culturale Române, București.

Coșeriu, E. (1997a). Sincronie, diacronie și istorie. Problema schimbării lingvistice, versiune în limba română de Nicolae Saramandu, Editura Enciclopedică, București.

Coșeriu, E. (1997b). [Principiile cercetării de tip umanist], în „Analele Academiei Române”, anul 126 (1992), seria V, vol. III. [Editura Academiei Române, București], p. 277-278.

Coșeriu, E. (1999). Discurso de Investidura del Prof. Eugenio Coseriu, în vol. Discursos de investidura de „doctor honoris causa” de los profesores Carlos Castilla del Pino, Eugenio Coseriu, José Elguero Bertolini, Universidad Autónoma de Madrid, Madrid, p. 33-42.

Coșeriu, E. (2000). Lecții de lingvistică generală, traducere din spaniolă de Eugenia Bojoga, cuvînt înainte de Mircea Borcilă, Editura Arc, Chișinău.

Coșeriu, E. (2004a). Epistemologia lingvisticii, în vol. In memoriam Eugeniu Coșeriu, Editura Academiei Române, București, p. 87-94.

Coșeriu, E. (2004b). Despre principiile științei lingvistice, în E. Coșeriu, Prelegeri și seminarii la Universitatea „Lucian Blaga” din Sibiu, Editura Universității „Lucian Blaga”, Sibiu, p. 25-36.

Martínez del Castillo, J.G. (2011). Lingvistica rostirii. Logosul semantic şi logosul apofantic [2004], ediţie, traducere și cuvînt înainte de Cristian Pașcalău, Scriptor \& Argonaut, Cluj-Napoca.

Munteanu, C. (2010). Lingvistica integrală ca Organon pentru cercetările privind limbajul, în „Limba română”, (Chișinău), 20 (11-12), p. 110-123.

Munteanu, C. (2012). Pentru o justă înțelegere a conceptului de «semnificat» la Eugeniu Coșeriu, în „Anuar de lingvistică și istorie literară", 51, Editura Academiei Române, București, p. 259-276.

Munteanu, C. (2013). Influența lui Robin George Collingwood asupra lui Eugenio Coseriu, în Catană-Spenchiu, A. \& Repciuc, I. (eds), Flores Philologie. Omagiu profesorului Eugen Munteanu, la împlinirea vârstei de 60 de ani, Editura Universității „Alexandru Ioan Cuza”, Iași, p. 442-460.

Munteanu, C. (2015). John Dewey și Eugeniu Coșeriu despre necesitatea exprimării (libere) în știință, în „Meridian critic” (Suceava), 24 (2), p. 133-138.

Munteanu, C. (2019a). Freedom and Libertinism in Culture. From José Ortega y Gasset to Eugenio Coseriu, în EIRP Proceedings, 14 [Danubius University Press, Galați], p. 421-424.

Munteanu, C. (2019b). Limbajul întreprețuire și disprețiire. Câteva aspecte, în „Limba română” (Chișinău), 29 (3), p. $100-106$. Ortega y Gasset, J. (1958). Man and Crisis, translated from Spanish by Mildred Adams, W.W. Norton \& Company, New York. Ortega y Gasset, J. (1961). History as a System, and other Essays toward a Philosophy of History, with and Afterword by John William Miller, translated by Helene Weyl, W.W. Norton \& Company, New York - London.

Ortega y Gasset, J. (1963). Concord and Liberty, translated by Helene Weyl, W.W. Norton \& Company, New York.

Ortega y Gasset, J. (1964). Obras Completas, Tomo V (1933-1941), sexta edición, Revista de Occidente, Madrid.

Ortega y Gasset, J. (1965a). Obras Completas, Tomo VIII (1958-1959), segunda edición, Revista de Occidente, Madrid.

Ortega y Gasset, J. (1965b). Obras Completas, Tomo IX (1960-1962), segunda edición, Revista de Occidente, Madrid.

Ortega y Gasset, J. (1966). Obras Completas, Tomo I (1902-1916), séptima edición, Revista de Occidente, Madrid.

Ortega y Gasset, J. (1971). The Idea of Principle in Leibnitz and the Evolution of Deductive Theory, translated by Mildred Adams, W.W. Norton \& Company, New York.

Ortega y Gasset, J. (1972). Velázquez. Goya, traducere de Dan Munteanu, prefață de Andrei Ionescu, Editura Meridiane, București.

Ortega y Gasset, J. (1973a). Meditații despre Don Quijote și Gînduri despre roman, traducere, prefață, note și tabel cronologic de Andrei Ionescu, Editura Univers, București. 
Ortega y Gasset, J. (1973b). An Interpretation of Universal History, translated by Mildred Adams, W.W. Norton \& Company, New York.

Ortega y Gasset, J. (1984). Historical Reason, translated by Philip W. Silver, W.W. Norton \& Company, New York - London. Ortega y Gasset, J. (1995). Studii despre iubire, traducere de Sorin Mărculescu, Humanitas, București.

Ortega y Gasset, J. (1997a). Spania nevertebrată. Schiță de reflecții istorice, traducere din spaniolă, note și cuvînt înainte de Sorin Mărculescu, Humanitas, București.

Ortega y Gasset, J. (1997b). Tema vremii noastre, traducere din spaniolă și prefață de Sorin Mărculescu, Humanitas, București. Ortega y Gasset, J. (1999a). Misiunea Universității, traducere și prefață de Andrei Ionescu, Editura Univers, București.

Ortega y Gasset, J. (1999b). Idei și credințe (și alte eseuri de filosofie), traducere din limba spaniolă de Doina Lincu, Editura Științifică, București.

Ortega y Gasset, J. (1999c). O interpretare a istoriei universale (pornind de la Toynbee), traducere din limba spaniolă de Esdra Alhasid, Editura Științifică, București.

Ortega y Gasset, J. (1999d). Ce este filozofia? Ce este cunoaşterea?, cu o introducere de Manuel García Morente, traducere din spaniolă de Sorin Mărculescu, Humanitas, București.

Ortega y Gasset, J. (1999e). Cîteva lecții de metafizică, traducere din spaniolă de Sorin Mărculescu, Humanitas, București.

Ortega y Gasset, J. (2000). Dezumanizarea artei (și alte eseuri de estetică), traducere din spaniolă, prefață și note de Sorin Mărculescu, Humanitas, București.

Ortega y Gasset, J. (2001). Omul și mulțimea, traducere din spaniolă și note de Sorin Mărculescu, Humanitas București.

Ortega y Gasset, J. (2002). Europa și ideea de națiune (și alte eseuri despre unele probleme ale omului contemporan), traducere din spaniolă și note de Sorin Mărculescu, Humanitas, București.

Ortega y Gasset, J. (2004). Originea și epilogul filozofiei (și alte eseuri filozofice), traducere din spaniolă și note de Sorin Mărculescu, Humanitas, București.

Ortega y Gasset, J. (2007). Revolta maselor [1994], traducere din spaniolă de Coman Lupu, ediția a III-a, Humanitas, București.

Whitehead, A.N. (1967). Adventures of Ideas [1933], The Free Press, New York. 